\title{
SWOT Analysis As A Competitive Strategy At Primkop Kartika Ardagusema Cimahi City, West Java, Indonesia
}

\author{
Wiara Sanchia Grafita Ryana Devi ${ }^{1 *}$, Desty Rara Pringgandinie ${ }^{2}$, Henly Yulina ${ }^{3}$, \\ Deni Hadiansah ${ }^{4}$ \\ ${ }^{1,2,4}$ Universitas Insan Cendekia Mandiri, Indonesia \\ ${ }^{3}$ Universitas Bale Bandung, Indonesia \\ *Corresponding Author: \\ Email: sanchiawiara@gmail.com
}

\begin{abstract}
.
In the current era of globalization, companies must be able to design a competitive strategy so as not to compete with other companies, a competitive strategy is one way for companies to find out their competitiveness in every strength that exists in a company. Every company must have a competitive advantage that other companies do not have. To design a competitive strategy the company can use a SWOT analysis. The effective use of SWOT analysis can play an important role in determining competitive strategies, in order to know the strengths, weaknesses, opportunities and threats faced by the company in maintaining the company's survival. The purpose of this study was to determine whether SWOT analysis is an appropriate strategy in increasing company production and how competitive strategies are carried out by a company to be able to compete in the era of globalization. This research data collection uses secondary data in obtaining data, archives, and documents. From the research that has been done, it is found that the results of the data that have been analyzed using a SWOT matrix from several internal factors, in the form of strengths and weaknesses, as well as external factors in the form of opportunities and threats to determine the competitive strategy for the Kartika Ardagusema Cooperative, is to carry out a diversification strategy (product, market).
\end{abstract}

Keywords: SWOT Analysis, Competitive Strategy.

\section{INTRODUCTION}

Today's business competition is getting fiercer. The number of homogeneous products on the market makes it increasingly difficult for businesses to establish a strategy to be superior to its competitors in order to achieve the expected performance. One of them is a business in the field of cooperatives. In particular, there are many basic legal provisions that encourage cooperatives to play a role in business institutions. In the context of developing cooperatives as a business field, a superior and appropriate strategy is needed in order to better support the development of economic activities with the aim and purpose of taking action in the welfare of the community. Therefore, the emphasis will be on clarifying the importance of having a form of business entity that is managed by and for the community. The importance of building and developing economic activities that are in accordance with the context of economic activities that aim to increase the added value of available resources that 
have been developed and have close links with existing business approaches and economic activities. The founder of a cooperative business certainly has the hope that the cooperative business he builds is considered important and the development of its activities also has insight towards improving the dignity of the community, both directly and indirectly. In increasing the development of a cooperative, it is necessary to prepare human resources related to cooperative management and also cooperative development strategies. The discussion on cooperative development becomes very relevant and requires a high commitment and also to build a competitive strategy in order to be able to have strong competitiveness with its competitors.

According to research by Aprilia and Ulfi Dista [1] in designing a competitive strategy, a SWOT analysis function is needed whose purpose is to be able to analyze and evaluate the strengths, weaknesses and competitive advantages of the company or business carried out through analysis of the company's internal conditions, as well as analysis of the company's internal conditions. regarding the opportunities and threats faced by the company through an analysis of the company's external conditions. According to research by Asmawati and Hanifah [2], the required process involves a determination with specific goals and has business speculation or also a project to identify internal and external environmental factors that have an influence on the strategic pattern of an institution or institution in achieving a goal. In line with the research of Farah and Dinnia Ainul [5] Analysis is also a part of the planning process of a company or institution, the main thing that is targeted is, in the competitive strategic planning process an institution requires an assessment of the current condition and an overview of the current situation. in the future that has an influence on the planning process of institutional goals and results in the existence of the main characteristics of strengths, weaknesses, and also sees an opportunity.

Kartika Ardagusema Cooperative is a functional Savings and Loan Business Unit within the Army which is carried out according to the provisions and policies given by the command (leader) in order to provide welfare for members and their families. Kartika Ardagusema Cooperative was founded on April 17, 1617 under the name PRIMKOPAD PUSSENART which is located on Jl. Baros No. G-151, Cimahi, Baros Village, Central Cimahi District as stated in the Legal Entity Number: 098/BH/VII/III-B on June 1, 1967. By designing a SWOT analysis as a competitive strategy Primkop Kartika Ardagusema has the intention of: provide direction and guidance for Primkop Kartika Ardagusema Management in carrying out their duties and functions, especially in the next 5 (five) years, namely from 2017 to 2021 . And also has the goal of optimizing the main tasks, functions and roles of Management in achieving the target of achieving the Medium Term Income Plan and to serve as a reference in the preparation of the Annual Work Plan for the Management and Cooperative Management.

From the background described above, the formulation of the problem that will be raised and discussed is "How is the effectiveness of the implementation of SWOT 
analysis on competitive strategies based on the strengths, weaknesses, opportunities and threats (SWOT) in the Kartika Ardagusema Cooperative?". In order to answer the formulation of the problem to be discussed, therefore the author uses a cooperative literature review and SWOT analysis. Thus, this research is expected to be a recommendation material for various cooperative management strategies to improve the quality of services for cooperative members.

\section{LITERATURE REVIEW \\ Definition of swot analysis}

SWOT analysis is the identification of various factors systematically to formulate corporate strategy. This analysis is based on logic that can maximize Strengths and Opportunities, but simultaneously minimize Weaknesses and Threats $[3 ; 15 ; 16]$.SWOT analysis is a tool that can be useful in the business world. This SWOT Analysis method is an analysis that is quite good, effective and efficient as well as a fast and precise tool in finding and recognizing possibilities related to new innovations in the business world [4].

\section{SWOT Analysis Factor}

Strengths, Weaknesses, Opportunities and Threats.

\section{SWOT Matrix}

The SWOT matrix is a tool used to compile the company's strategic factors. This matrix can describe how the external opportunities and threats faced by the company can be adjusted to the strengths and weaknesses it has. This matrix can produce 4 sets of possible strategic alternatives [6].

The SWOT matrix is an important matching tool to help develop four types of strategies, namely as follows [6]:

1. SO (Strength-Opportunity) strategy is a strategy to use the company's internal strengths to seize opportunities that exist outside the company.

2. WO (Weakness-Opportunity) strategy, this strategy aims to minimize the company's internal weaknesses by taking advantage of company opportunities.

3. ST strategy (Strength-Threat), through this strategy the company tries to avoid or reduce the impact of external threats.

4. WT strategy (Weakness-Threat), this strategy is a tactic to survive by reducing internal weaknesses and avoiding threats.

\section{Competitive Strategy}

The company must be ready to compete in global competition, the company must have a competitive advantage compared to its competitors. Khoiriyah and Binti Alfi [7] provide an understanding that competitive advantage is a unique position developed by an organization in an effort to beat competitors. Meanwhile, Nurhayati and Ratih [8] distinguish competitive advantage according to the traditional view with sustainable competitive advantage according to the resource-based view. According to 
the traditional view, resources already owned by firms in the same industry have the property of being bought or adopted easily by other firms. Meanwhile, sustainable competitive advantage according to the resource-based view can be achieved if the resources and capabilities of the company are homogeneous, different from other companies or competitors, and other companies or competitors do not have the ability to obtain similar resources. Meanwhile, according to Pujiati's research [9] a company is said to have a competitive advantage if it meets the following characteristics:

1. Special competencies, for example having a product with better quality, having a smoother distribution channel, faster product delivery, having a more well-known product brand.

2. Creating imperfect competition. In a perfectly competitive market, every company can enter and leave the market easily, so companies that want to find a competitive advantage must get out of the perfectly competitive market.

3. Sustainability, meaning that competitive advantage must be sustainable and uninterrupted.

4. Suitable for external environments. The external environment presents opportunities and threats to companies that are competitive.

5. The profit earned is higher than the average profit of other companies.

\section{Types of Competitive Strategy}

In knowing the competitiveness of a company you must be aware of the strengths of rival companies. Nisak and Zuhrotun suggest that companies can use one of three strategies: differentiation, cost leadership, or focus. The company's biased characteristics are associated with each strategy [10].

1. Differentiation Strategy

2. new competitors through customer loyalty that is difficult to overcome.

3. Leadership Strategy

4. Focus Strategy.

\section{Formulating Competitive Strategy}

An effective way to formulate strategy is the five competitive forces and strategies [7] examined a number of firms and stated that the enterprise-level strategy is the result of the five competitive forces in the firm's environment.

\section{Execution time}

Data collection in this study was carried out at the Kartika Ardagusema Cooperative, from November to December 2021, to be precise, from November 22, 2021 to December 6, 2021. The Kartika Ardagusema Cooperative is located at Jalan Baros No. G.151, Cimahi.

\section{METHODS}

Essentially the analysis of the data is the process of simplification of the data to be more easily read and to be represented. Data were there to be analyzed into a form that 
is simple to further sought the meaning and implications are more spacious than the results of the study $[11 ; 12]$. Methods of analysis are used in research.

This is the method of descriptive analysis and analysis of SWOT. Descriptive analysis method is used to analyze SWOT analysis as a competitive strategy.

\section{SWOT analysis}

SWOT stands for Strengths and Weaknesses of the internal environment and Opportunities and Threats of the external environment in the business world [13]. SWOT analysis in this study is used to determine the method of development strategy by analyzing external factors in the form of opportunities and threats and internal factors in the form of strengths and weaknesses. In the strategic planning process, there are three stages of analysis, namely the data collection stage, the analysis stage, and the decision - making stage. In the first stage, namely the data collection stage, an evaluation of external and internal factors is carried out to obtain the required data.

The next stage is stage [17].Analysis where at this stage there are several models of analytical tools, namely; matrix tows, matrix BCG matrix internal-external, matrix space, and matrix grand strategy. Increasingly many matrices are used in the analysis, the analysis that is done will be more accurate. The last stage of the strategic planning process is the decision-making stage where at this stage a quantitative strategic planning matrix can be used to facilitate strategy selection. In this study, for the data collection stage, the external strategy factor matrix and the internal strategy matrix will be used [14].

\section{RESULT AND DISCUSSION Research result}

From the results of the SWOT analysis include the strengths, weaknesses, opportunities and threats to the Kartika Ardagusema Cooperative:

\section{Strength}

1. Potential Utilization of Appropriate Technology for Cooperatives

2. The potential (quality) of the Cooperative is very likely to be developed.

3. Cooperative empowerment is very strategic to be embraced, especially in the context of accelerating the welfare of members.

4. Cooperatives have independence in business, are strong, and flexible in anticipating and adapting to the dynamics of market changes (developments).

5. Ability in mastering information and communication technology including marketing promotion and lobbying.

6. The potential of manufacturing and educational resources in Central Cimahi District and its surroundings has the potential to support the development of the industrial and education sectors which have high economic value and competitiveness in the form of comparative advantage. 
7. Occupation/human resources (community groups) which are potential supporters of the development of the trade sector both as business actors, laborers and as potential market share

8. It is hoped that a well-run organizational consolidation process will be able to produce harmonious and integrated synergies in spurring the development of the economic and trade sectors in this region.

\section{Weakness}

1. Access to Technology Cooperatives use simple technology and do not use technology that adds value to members.

2. Members' understanding of cooperatives is still not good.

3. The number of cooperatives that have problems and abuse the provisions (lenders) so that it affects price/interest competition.

4. There are limitations in the areas of capital, market opportunities and human resources.

5. Product quality has not been optimally competitive.

6. Limited information technology owned by human resources.

7. There is no accurate information system and business database for members.

8. The absence of legal power in making investments when there is a price fluctuation in the market for farmers who are members of the cooperative.

9. There are still limited quality human resources who are expected to be able to explore and manage potential natural resources in Rendang District.

10. There is still limited analysis that can make technological/appropriate innovations for the development of room, kiosk, and yard rental businesses based on Agribusiness and Agro-Industry for members.

11. The organizational apparatus has not yet been developed to a lower level so that the guidance, regulation and development of cooperatives is still limited.

12. The limited facilities to support coaching activities, especially when faced with wide field conditions and limited infrastructure, make member development an obstacle.

13. It is still necessary to continue to improve the professionalism of the supervisory apparatus/management staff so that they are able to anticipate the dynamics of the business world development which is very fast and changes all the time, especially in the formation of members who have an entrepreneurial spirit (pro business oriented), through continuous training.

14. Changes in tax policies that change from time to time in the army environment. Opportunity

1. The growth of micro and small business groups, especially for member families.

2. The opening of internet network access in JNE's business.

3. Increased access to capital through member time deposits. 
4. The increasing attention and government policies that encourage the creation of a more conducive and healthy business climate.

5. The ease of communicating and disseminating information quickly and accurately to the global community will support the acceleration of trade business development.

6. The implementation of regional autonomy can be an opportunity for the implementation of more intensive and targeted apparatus development according to the needs of cooperatives

\section{Threat}

1. Limitations of Creative industry infrastructure.

2. Access to capital from financial institutions is difficult to obtain due to requirements.

3. Cooperative human resources are not sufficient.

4. The increase in similar institutions so that members are less interested in shopping at the Cooperative.

5. There is still a lack of efforts to improve human resources either through training, continuing education, seminars and the like.

\section{Discussion}

It is known the strengths, weaknesses, opportunities and threats that exist in the Kartika Ardagusema Cooperative, therefore it makes it easier to prepare an operational program plan which is an operational activity plan that can support the implementation of the main tasks and functions of the organization that has been established in order to achieve the goals that have been set. , by trying to utilize all available resources and take advantage of an existing opportunity and overcome weaknesses and anticipate threats that will arise in the future in line with research $[5 ; 1 ; 2 ; 4]$. Therefore Primkop Cooperative Kartika Ardagusema compiled a program for the period 2017-2021, which is as follows:

Business Productivity Improvement Program:

1. Entrepreneurship development in members.

2. Cooperative product development that has high competitiveness and is member-based.

3. Increasing employee productivity through the use of technology with the support of professional human resources.

4. Improvement and development of promotion and business information network as well as business partnerships.

5. Development of marketing and business networks. 
Business Supporting Climate Improvement Program:

1. Improvement and development of reliable business organization and management.

2. Primkop Kartika Ardagusema business improvement and development in providing business services to small and medium enterprises.

3. Increasing employee productivity through the use of technology with the support of professional human resources.

4. Improvement and development of promotion and business information network as well as business partnerships.

5. Development of marketing and business networks.

Institutional Quality Improvement Program:

1. Preparation of cooperative work programs.

2. Improved member development, management, capital and cooperative business.

3. Cooperative empowerment.

4. Mentoring, evaluation and reporting.

5. Increase partnership support.

6. Improve coordination and cooperation with related agencies.

Business Support System Development Program :

1. Preparation of programs and data collection of members' businesses.

2. Monitoring member business activities.

3. Development of infrastructure suggestions.

4. Guidance and development of human resources, production, marketing, and technology for members.

5. Facilitate access to guarantees in providing financing for members.

6. Supervision, monitoring, and evaluation for members.

7. Improved network among members.

8. Implementation of member training.

Member Entrepreneurship Development Program:

1. Implementation of entrepreneurship training.

2. Sarpras support.

Empowerment of People's Economy:

1. Development of human resources and business opportunities for the needs of members.

2. Development of Service Quality for members.

3. Development of business facilities, partnerships and business units.

4. Funding, Usipa, Toko and Tiki.

5. Quality development.

6. Business development.

7. Creating a conducive business climate. 


\section{Competitive Strategy}

Based on the results of the data that has been analyzed using a SWOT matrix from several internal factors, in the form of strengths and weaknesses, as well as external factors in the form of opportunities and threats to determine a competitive strategy for the Kartika Ardagusema Cooperative is to carry out a diversification strategy (product, market), namely: ST [2;5]

\section{ST Strategy:}

1. Entrepreneurship development in members.

2. Cooperative product development that has high competitiveness and is member-based.

3. Ensuring the quality of goods sold in the Cooperative.

4. Increasing employee productivity through the use of technology with the support of professional human resources.

5. Improvement and development of promotion and business information network as well as business partnerships.

\section{CONCLUSION}

SWOT analysis is a useful weapon to face increasingly fierce competition. This analysis can be used as a tool and application of decision-making tools in the context of introducing new programs in an organization or partnership. In the SWOT analysis process, it is necessary to have an internal survey regarding Strengths , Weaknesses of the organization/activities within the organization or something to be studied, as well as an external survey on Opportunities, and Threats . In addition to SWOT analysis, companies need a Competitive Strategy, because a competitive strategy is an achievement in a coveted competitive position within a company. The goal is to create an advantage and a favorable position against the forces that determine industry competition. A company can be said to have a competitive advantage when it has something that competitors do not have, does something better than other companies, or is able to do something that other companies cannot.

After the author studied the circumstances that occurred in the company, the author suggested that the Kartika Ardagusema Cooperative pay attention to the following matters:

1. Cooperatives must maintain and also be able to maintain the quality of service for both its members and consumers.

2. Cooperatives must always provide products with good quality, and routinely check the quality of goods every month.

3. Cooperatives are expected to always improve and develop promotions and business information networks and business partnerships. 


\section{REFERENCES}

[1] Aprilia and Ulfi Dista. 2018. Analysis of Strengths, Weaknesses, Opportunities, and Threats on the Development of the Batik Industry in Tulungagung in an Islamic Economic Perspective (CV Saha Perkasa Gajah Mada). IAIN Tulungagung Repository

[2] Asmawati and Hanifah. 2018. Business Development Strategy with SWOT Analysis Method at Istiqomah Laundry Business in Samarinda. Journal of Business Administration, Vol 6, No 1

[3] David and Fred R. 2014. SWOT Analysis of Business Case Dissecting Techniques. Jakarta: Gramedia Pustaka Utama

[4] Freddy Rangkuti. 2004. SWOT Analysis of Dissecting Business Case Techniques, PT. Gramedia, Jakarta.

[5] Farah and Dinnia Ainul. 2018. "SWOT Analysis in Determining Competitive Advantage Strategy at the Souvenir Center (Case Study CV Nabata Souvenir, Kendalrejo Village, Talun District, Blitar Regency)". IAIN Tulungagung Repository

[6] Siagian, Sondang P. 2011. Strategic Management. Jakarta: PT Bumi Aksara

[7] Khoiriyah and Bint Alfi. 2018. "Strategy for Development of Cemara Sewu Tourism Facilities Tulungagung to Attract Tourists". IAIN Tulungagung Repository

[8] Nurhayati and Ratih. 2009. Formulation of Company Strategy Based on SWOT Analysis, (Case Study of PT Mondrian). Yogyakarta: Sanata Dharma University

[9] Praise. 2018. Analysis of Strengths, Weaknesses, Opportunities, Threats in Determining Marketing Strategy for the Home Industry Hanger "Rooster". IAIN Tulungagung Repository

[10] Nisak and Zuhrotun. 2013. SWOT Analysis To Determine Competitive Strategy. Ekbis Journal Vol 9 No 2.

[11] Moleng. Lexy, j. 2013. Qualitative Research Methodology. Bandung: Youth Rosda Karya

[12] Gunawan and Faith. 2013. Qualitative Research Methods Theory and Practice. Jakarta: PT Bumi Aksara

[13] Setiawan Robi. 2015. The Application of SWOT Analysis as the Basis for Formulating the Marketing Strategy of the "AMAN-AMIN" Car Rental Service Business Transport Tours and Travel Ambarketawang Sleman Yogyakarta. Yogyakarta: Yogyakarta State University

[14] Riduwan. 2004. Research Methods. Jakarta : Rineka Cipta

[15] Nulow, Yulia and Mulyana, Mumuh. 2012. Analysis of Retail Location Strategy and Store Image of Giant Botani Square Bogor. Unity Scientific Journal. Vol. 14 No. 1. Bogor: STIE Unity.

[16] Widajanti E. 2012. Effective Human Resource Planning: A Strategy for Achieving Competitive Advantage

[17] Umar, Husayn. 2001. Strategic management in action. Jakarta: PT Gramedia Pustaka Utama 